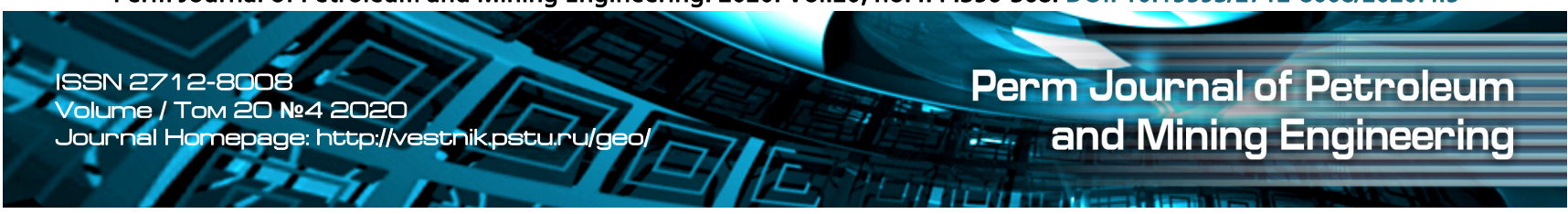

UDC 622.276

Article / Статья

(c) PNRPU / ПНИПУ, 2020

\title{
Assessing the Impact of Uncertainty Parameters on Forcasting Production Parameters
}

\author{
Nikita D. Kozyrev, Aleksey Yu. Vishnyakov, Ivan S. Putilov \\ PermNIPIneft branch of LUKOIL-Engineering LLC in Perm (3a Permskaya st., Perm, 614015, Russian Federation)
}

\section{Оценка влияния параметров неопределенности на прогнозирование показателей разработки}

\section{Н.Д. Козырев, А.Ю. Вишняков, И.С. Путилов}

Филиал ООО «ЛУкОЙЛ-Инжиниринг» «ПермНИПИнефть» в г. Перми (Россия, 614015, г. Пермь, ул. Пермская, 3а)

PermNIPIneft branch of LUKOIL-Engineering LLC in Perm (3a Permskaya st., Perm, 614015, Russian Federation)

\section{Received / Получена: 03.04.2020. Accepted / Принята: 25.08.2020. Published / Опубликована: 26.10.2020}

Keywords:

uncertainty parameters, multivariant simulation, stochastic analysis, model adaptation, forecast of production process parameters, adjustment of oil production levels, sensitivity analysis, incremental oil production, equilibrium adaptation options, sector model, probabilistic risks assessment, percentile, mathematical expectation, factor analysis.

\section{Ключевые слова}

гидродинамическое моделирование, параметры неопределенности, многовариантное моделирование, стохастический анализ, адаптация модели, прогноз технологических параметров разработки, уточнение уровней добычи нефти, анализ чувствительности, прирост добычи нефти, равновесные варианты адаптации, секторная модель, вероятностная оценка рисков, перцентиль, математическое ожидание, факторный анализ.
At the stage of developing a geological and hydrodynamic reservoir model, uncertainties in input data may lead to errors in simulation results and subsequent inaccurate economic evaluations of oil or gas field potentials.

In order to improve predictive reliability, a study was completed to assess how input data of a hydrodynamic model influence forecasts of main parameters of a production using the example of the Tournaisian site of the Soldatovskoye field.

The study presents an approximate algorithm reducing uncertainties and improving the forecast reliability of the production parameters obtained using a geological and hydrodynamic reservoir model. The algorithm includes a substantiated selection of the initial sensitivity parameters, an evaluation of the impact of the initial parameters on the hydrodynamic reservoir model using the sensitivity analysis, as well as a selection of an optimal range of variations of the uncertainty parameters as a result of the multivariant hydrodynamic simulation adaptation, calculation and analysis of the multivariant hydrodynamic reservoir model forecast.

The study aims to clarify the design process parameters of the development, assess the risks of non-confirmation of the hydrodynamic simulation forecasting, and make recommendations and proposals to study those uncertainty parameters, which influence most on certain predicted production parameters of an asset. As a result, a block diagram of the approach is presented in order to generalize and replicate it on potential and important oil and gas fields.

The described approach of the model adaptation and calculations of the predicted options in conditions of uncertainty of the initial model parameters make it possible to obtain a more accurate and less arbitrary hydrodynamic reservoir model, which reduces probability of an incorrect evaluation of potentials of a young field or a field at an early production stage.

Неопределенности исходных данных при создании геолого-гидродинамической модели пласта могут привести к погрешности результатов моделирования и, следовательно, к неверной экономической оценке и перспективе нефтяного или газового месторождения.

C целью повышения прогнозной надежности осуществлена оценка влияния исходных параметров гидродинамической модели на прогноз основных технологических показателей разработки на примере турнейского объекта Солдатовского месторождения.

В исследовании представлен ориентировочный алгоритм, позволяющий снизить неопределенности и повысить надежность прогноза технологических показателей разработки, полученного с помощью геолого-гидродинамической модели пласта. Алгоритм включает в себя обоснованный выбор исходных параметров неопределенности, оценку степени влияния исходных параметров на гидродинамическую модель пласта с помощью анализа чувствительности, выбор оптимального диапазона изменения параметров неопределенности в результате многовариантной адаптации гидродинамической модели, расчет и анализ многовариантного прогноза гидродинамической модели пласта.

Итогом работы является уточнение проектных технологических показателей разработки, оценка рисков неподтверждения прогноза гидродинамической модели, а также рекомендации и предложения по исследованию тех параметров неопределенности, которые оказали наибольшее влияние на расчетные технологические показатели разработки объекта. Как итог представлена блок-схема применяемого подхода с целью обобщения и тиражирования на перспективных и значимых месторождениях нефти и газа.

Описываемый подход адаптации модели и расчета прогнозных вариантов в условиях неопределенности исходных параметров модели позволит получить более достоверную и менее субъективную гидродинамическую модель пласта, что, в свою очередь, снизит вероятность неверной оценки перспективы «молодого» месторождения или месторождения, разрабатываемого на ранней стадии. e-mail: Ivan.Putilov@pnn.lukoil.com).

Козырев Никита Дмитриевич - инженер I категории отдела создания и мониторинга гидродинамических моделей приоритетных месторождений (тел.: +007 3422353405 , e-mail: Nikita.Kozyrev@pnn.lukoil.com). Контактное лицо для переписки.

Вишняков Алексей Юрьевич - ведущий специалист отдела оптимизации добычи (тел.: + 0073422336 291, e-mail: Aleksej.Vishnyakov@pnn.lukoil.com)

Путилов Иван Сергеевич - доктор технических наук, заместитель директора по научной работе в области геологии (тел.: + 0073422336291 , e-mail: Ivan.Putilov@pnn.lukoil.com). 


\section{Introduction}

To increase efficiency of oil field productions, it is required to build geological and hydrodynamic models (GHM) for production sites. A dydrodynamic model is intended to provide the most precise description of permeability parameters, as well as physical and chemical processes characteristic of an actual reservoir [1-7].

In Perm Krai, small-scale oil fields are in priority. Due to small volumes and mobility of geological reserves, input data errors may lead to incorrect evaluations of a field's potential. Thus, a review of initial data uncertainties is required to obtain reliable forecasts during the design process, and at the stage of building hydrodynamic models of fields at early production stages.

An uncertainty is a state of a full or partial absence of information about a site to be modeled, which is required to understand a certain event, its consequences and their probability [8-12].

The purpose of the study is to improve certainty of forecasting main process parameters of fields at early production stages.

\section{Current Status of the Tournaisian Site Development in the Soldatovskoye Field}

The Tournaisian site in the Soldatovskoye field havs been developed since 2012. The asset contains several uplifts, including the Kukleyanovskoye uplift. The latter is of interest as it holds $47 \%$ of geological oil reserves of the Tournaisian site.

In 2017, the asset reached an early development stage with the current production well stock of eight horizontal wells. Current oil rates vary from 1.3 to $27.9 \mathrm{t} /$ day. The watering rate of the producing wells is from 4.8 to $93.0 \%$ (Fig. 1).

The production diagram analysis reveals that the weighted average reservoir pressure within the site is preserved at the level of $17 \mathrm{MPa}$. However, in the area of producing wells 404 and 403 at the Kukleyanovskoye uplift, the reservoir pressure is decreased by 41-54\%, compared to the initial pressure (from 17.5 to $8 \mathrm{MPa}$ ), when the saturation pressure is $10.2 \mathrm{MPa}$.

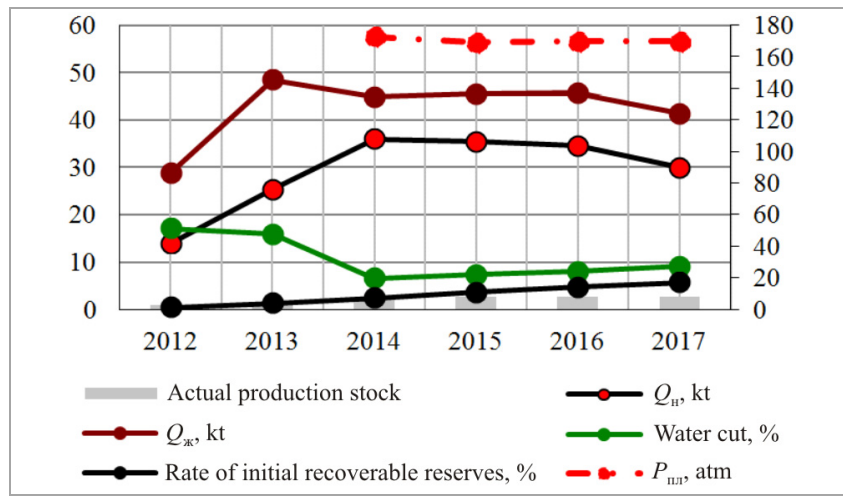

Fig. 1. Production diagram, the Soldatovskoye field, the Tournaisian site

Table 1

Geological and physical characteristics of the Tournaisian site in the Soldatovskoye field

\begin{tabular}{lc}
\hline \multicolumn{1}{c}{ Parameter } & $\begin{array}{c}\text { Kukleyanovskoye } \\
\text { uplift }\end{array}$ \\
\hline Average roof depth, $\mathrm{m}$ & $1,803.5$ \\
\hline Reservoir type & Carb. \\
\hline Average effective oil-filled thickness, $\mathrm{m}$ & 8.9 \\
\hline Porosity factor, decimal fraction & 0.12 \\
\hline Permeability, um ${ }^{2}$ & 0.0145 \\
\hline Sand factor, decimal fraction & 0.443 \\
\hline Partitioning, decimal fraction & 10.4 \\
\hline Initial reservoir pressure, $\mathrm{MPa}$ & 17.5 \\
\hline Oil viscosity at reservoir conditions, $\mathrm{mPa} \cdot \mathrm{sec}$ & 13.7 \\
\hline Oil density at surface conditions, $\mathrm{g} / \mathrm{cm}^{3}$ & 0.912 \\
\hline Saturation pressure, $\mathrm{MPa}$ & 10.2 \\
\hline Gas factor, $\mathrm{m}^{3} / \mathrm{t}$ & 38.8 \\
\hline Displacement ratio, decimal fraction & 0.56 \\
\hline Productivity factor, $\mathrm{m}^{3} /$ day $\mathrm{MPa}$ & 3.4 \\
\hline
\end{tabular}

Table 1 gives a brief overview of geological and physical characteristics of the Tournaisian site.

In order to optimize time consumed for GHM calculations, a separate sector model was built for the Kukleyanovskoye uplift with a geological model (GM) level of detail. The number of active cells reduced seven times, while the calculation time was 15 times quicker. For initialization, an aquifer was created at the sector model borders using the Carter-Tracy aquifer flow model.

\section{Justification of Selecting the Uncertainty Parameters}

At the adaptation stage of per-well actual rates, an adequate creation of the hydrodynamic model was complicated due to low absolute 
permeability values. Based on geophysical well logging (GWL) results, the average absolute permeability value for the uplift under study was adopted as $14.5 \mathrm{mD}$. As a result, it was decided to consider hydrodynamic researches (HR), which established that the farfield reservoir (FR) permeability at one of producing wells was $787 \mathrm{mD}$ in 2012 and $23 \mathrm{mD}$ in 2014 . Taking into account the difference in permeability values obtained with the HR and GWL studies, and also variations in permeability values obtained with HR during the reservoir pressure reduction, we may assume that there was a fracture system [13-19].

The rock permeability containing a fracture system is known to depend on the reservoir pressure to a much greater extent vs. permeability of a porous medium. Supposedly, the reduction in the reservoir pressure in 2014 increased the external load on the rock skeleton, which resulted in a smaller openness of fractures. This decreased permeability from 787 to $23 \mathrm{mD}$ after performing HR in 2014 within the producing well area.

Presumably, values of the reservoir properties were incorrectly determined due to an incomplete GWL in the wells with a nominally horizontal borehole section, as they have a small diameter.

The analysis of the Kukleyanovskoye uplift resulted in the following parameters selected as uncertainty:

1. The absolute permeability parameter of an aquifer and oil-saturated reservoir parts to indirectly account for the Tournaisian reservoir fracturing.

2. The influence of the aquifer. It was modeled using the Carter-Tracy aquifer flow model, taking into account replacement zones. The Carter-Tracy aquifer maximally accounts for the aquifer property due to such parameters as average reservoir permeability, average reservoir porosity, a sum of the rock and water compressibility, an internal aquifer radius, an average effective thickness, an initial reservoir pressure, reservoir water viscosity. Given the underexplored level of the site, parameters of the average permeability, porosity, reservoir thickness and internal aquifer radius are taken as uncertainty.

3. Uncertainty of the rock phase permeabilities. Permeability values of the experimental phase exist only for two values of the absolute permeability at the Soldatovskoye field. Phase permeability curves were used for simulation, modified subject to the residual water saturation.

4. Uncertainty of the reservoir-to-well connectivity and skin factor. The connectivity and skin factor are selected as a parameter of uncertainty, as within time, the well has its hydrodynamic imperfection changed according to its penetration nature [20].

Table 2 presents boundary values of uncertainty parameters.

\section{Multivariant Simulation}

The next stage of the study implies performing a multivariant simulation with regard to the selected range of uncertain parameters using Enable software by Roxar [20-27]. In total 110 calculations were performed. Fig. 2 shows a diagram of the cumulative oil production for all options of the hydrodynamic model adaptation.

On basis of the obtained options of the model adaptation, their quality was evaluated, during which calculations complying with temporary rules of quality evaluations and acceptance of three-dimensional digital geologo-hydrodynamic models were selected. That is, a deviation of the calculated cumulative fluid and oil production will not exceed $5 \%$, while the deviation of the calculated annual fluid and oil production will not exceed $10 \%$. Table 3 shows adaptations results of boundary calculations, complying with the regulation. Calculations shown in Fig. 6 and distributed either above or below the boundaries, fall beyod the regulation range.

Table 2

Boundary values of uncertainty parameters

\begin{tabular}{|c|c|c|c|}
\hline \multirow{2}{*}{ Uncertainty parameter } & \multicolumn{3}{|c|}{ Value } \\
\hline & minimal & average & maximal \\
\hline $\begin{array}{l}\text { Aquifer permeability parameter, } \\
\text { Md }\end{array}$ & 14.5 & 25 & 207 \\
\hline Aquifer porosity parameter, \% & 0.08 & 0.12 & 0.17 \\
\hline $\begin{array}{l}\text { Parameter of average effective } \\
\text { aquifer thickness, m }\end{array}$ & 70 & 75 & 100 \\
\hline Internal radius of aquifer, $\mathrm{m}$ & 2,000 & 2,500 & 3,000 \\
\hline $\begin{array}{l}\text { Reservoir to well connectivity, } \\
\text { decimal fraction }\end{array}$ & 1 & 5 & 10 \\
\hline Skin factor & -10 & 0 & 10 \\
\hline $\begin{array}{l}\text { Single phase flow multiplier, } \\
\text { decimal fraction }\end{array}$ & 0.75 & 1 & 1.25 \\
\hline $\begin{array}{l}\text { Permeability multiplier (presence } \\
\text { of fraction networks), decimal } \\
\text { fraction }\end{array}$ & 1 & 1.5 & 2 \\
\hline
\end{tabular}




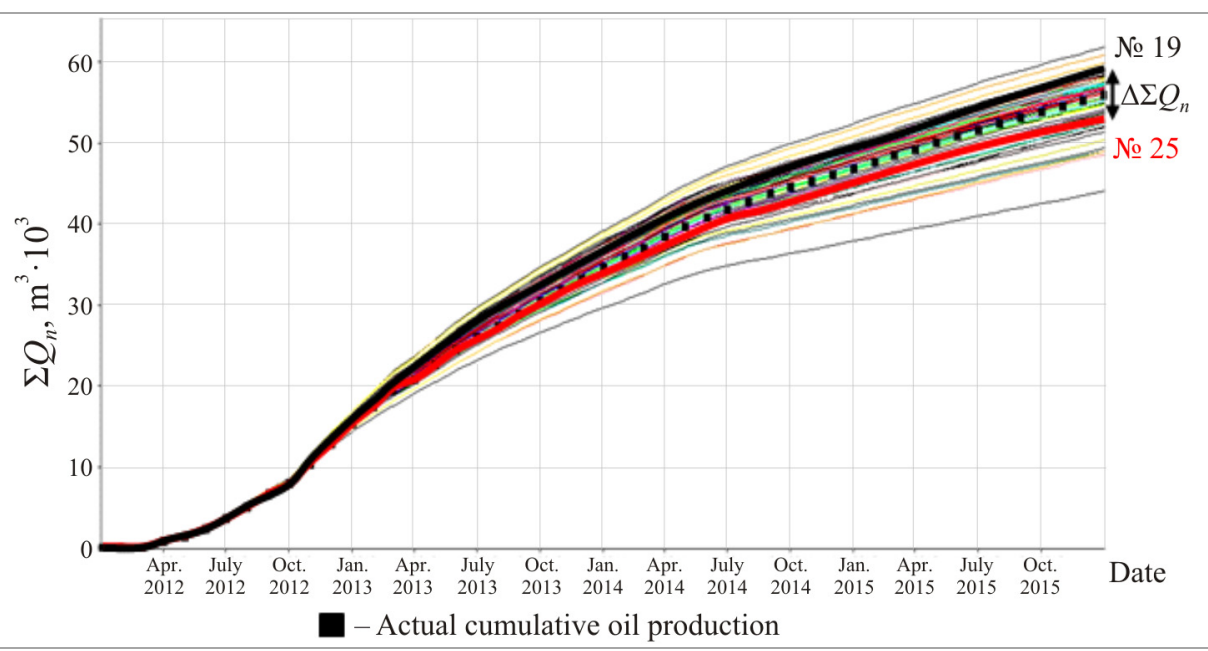

Fig. 2. Diagram of calculated cumulative oil production of all model adaptation options

Table 3

Adaptation results of boundary calculations

\begin{tabular}{|c|c|c|c|c|c|c|c|c|c|}
\hline \multirow[t]{2}{*}{ Year } & \multicolumn{2}{|c|}{$\begin{array}{l}\text { Fluid production, } \\
\text { thou. } \mathrm{m}^{3}\end{array}$} & \multirow[t]{2}{*}{$\Delta, \%$} & \multicolumn{2}{|c|}{ Oil production, thou. $\mathrm{m}^{3}$} & \multirow[t]{2}{*}{$\Delta, \%$} & \multicolumn{2}{|c|}{ Water saturation, \% } & \multirow[t]{2}{*}{$\Delta, \%$} \\
\hline & actual & calculated & & actual & calculated & & actual & calculated & \\
\hline \multicolumn{10}{|c|}{ Calculation \# 19} \\
\hline 2012 & 28.1 & 27.1 & 3.6 & 15.4 & 16.2 & -4.9 & 45.1 & 40.3 & 10.7 \\
\hline 2013 & 38.2 & 38.0 & 0.4 & 19.3 & 20.6 & -6.5 & 49.3 & 45.9 & 7.1 \\
\hline 2014 & 15.9 & 15.8 & 0.8 & 12.2 & 12.5 & -2.4 & 23.6 & 21.1 & 10.4 \\
\hline 2015 & 12.6 & 12.5 & 0.5 & 9.0 & 9.3 & -3.2 & 28.7 & 26.1 & 9.3 \\
\hline Total period & 94.8 & 93.4 & 1.4 & 55.9 & 58.5 & -4.6 & & & \\
\hline \multicolumn{10}{|c|}{ Calculation \# 25} \\
\hline 2012 & 28.1 & 28.1 & 0.0 & 15.4 & 15.2 & 1.7 & 45.1 & 46.1 & -2.0 \\
\hline 2013 & 38.2 & 38.0 & 0.5 & 19.3 & 19.2 & 0.8 & 49.3 & 49.5 & -0.3 \\
\hline 2014 & 15.9 & 15.6 & 2.3 & 12.2 & 11.6 & 4.5 & 23.6 & 25.3 & -7.4 \\
\hline 2015 & 12.6 & 12.6 & 0.0 & 9.0 & 8.2 & 8.5 & 28.7 & 34.8 & -21.2 \\
\hline Total period & 94.8 & 94.2 & 0.6 & 55.9 & 54.2 & 3.1 & & & \\
\hline
\end{tabular}

Corrected boundary values of uncertainty parameters

Table 4

\begin{tabular}{lccc}
\hline \multirow{2}{*}{ Uncertainty parameter } & \multicolumn{2}{c}{ Value } \\
\cline { 2 - 4 } & minimal & average & maximal \\
\hline Parameter of aquifer permeability, $\mathrm{mD}$ & 50 & 55 & 65 \\
\hline Parameter of aquifer porosity, $\%$ & 0.12 & 0.13 & 0.14 \\
\hline Parameter of average effective aquifer thickness, $\mathrm{m}$ & 85 & 90 & 95 \\
\hline Internal radius of aquifer, $\mathrm{m}$ & 2,289 & 2,392 & 2,544 \\
\hline Reservoir to well connectivity, decimal fraction & 1 & 5 & 10 \\
\hline Skin factor & -10 & 0 & 10 \\
\hline Rock wettability (single phase flow multiplier), decimal fraction & 1 & 1.25 & 1.25 \\
\hline $\begin{array}{l}\text { Permeability multiplier (presence of fracture networks), decimal } \\
\text { fraction }\end{array}$ & 1.45 & 1.5 & 1.55 \\
\hline
\end{tabular}




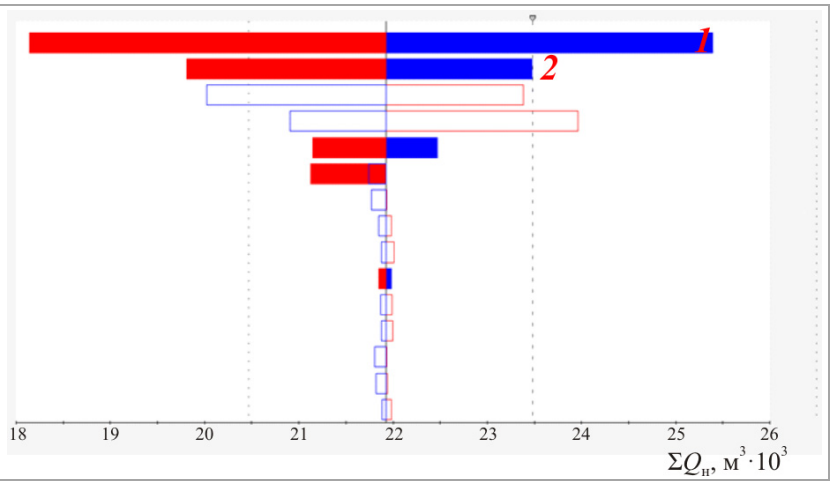

Fig. 3. Tornado diagram: 1) absolute permeability multiplier; 2) multiplier (single phase flow)

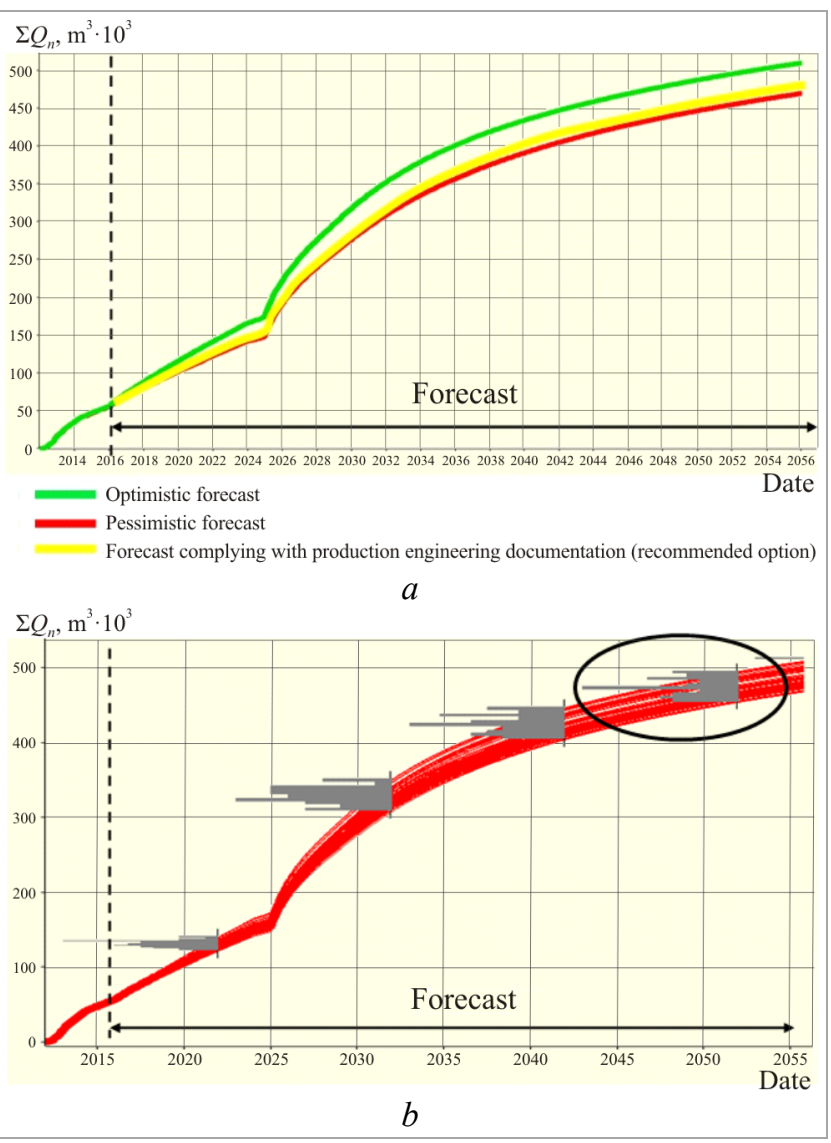

Fig. 4. Diagram of forecasted values: a) cumulative oil production; b) cumulative oil production with plotted

histograms of calculations density distribution

It is found that 77 calculations out of 110 fall within the regulation range, which is $70 \%$ of the total amount.

By the multivariant adaptation of GHM and further selection of calculations complying with the regulation, the variation range of the uncertainty parameters was narrowed, which resulted in corrected boundaries of the uncertainty parameters (Table 4) [28-31].
At the given values of the uncertainty parameters, all the calculations obtained by using GHM comply with the regulation. However, during calculations of the long-term forecast parameters, a significant deviation will be observed.

\section{Analysis of Influence of the Uncertainty Parameters on the Calculated Production Parameters}

During the study, sensitivity calculations were performed, which showed that parameters with the greatest impact on the model adaptation are the absolute permeability multiplier, which indirectly accounts for the reservoir fracturing, and relative phase permeabilities multiplier.

Tornado diagram in Fig. 3 shows an extent of variations in the cumulative oil production depending on values of the uncertainty parameters.

\section{Multivariant Forecasts using the Recommended Development System}

We performed the forecast calculations for the recommended option of adaptations complying with the regulations at the next stage related to evaluations of quality and determinations of parameters, which have the greatest influence on the model adaptation [32, 33].

As a result, optimistic (510 thou. $\mathrm{m}^{3}$ ) and pessimistic (469 thou. $\mathrm{m}^{3}$ ) options of the cumulative oil production forecast were obtained. The difference between them is 41 thou. $\mathrm{m}^{3}$ (Fig. 4).

By analyzing Fig. 4, a, one can see that the recommended forecast option is included into the highlighted area and is distributed closer to the pessimistic option. Further on, a probabilistic forecast assessment was performed using histograms characterizing a density of the distribution of calculations, according to values of the cumulative oil production (Fig. 4, b) [34].

Fig. 5 shows an enlarged histogram characterizing the density of the distribution of the cumulative oil production in 2056 with percentile marked up. 


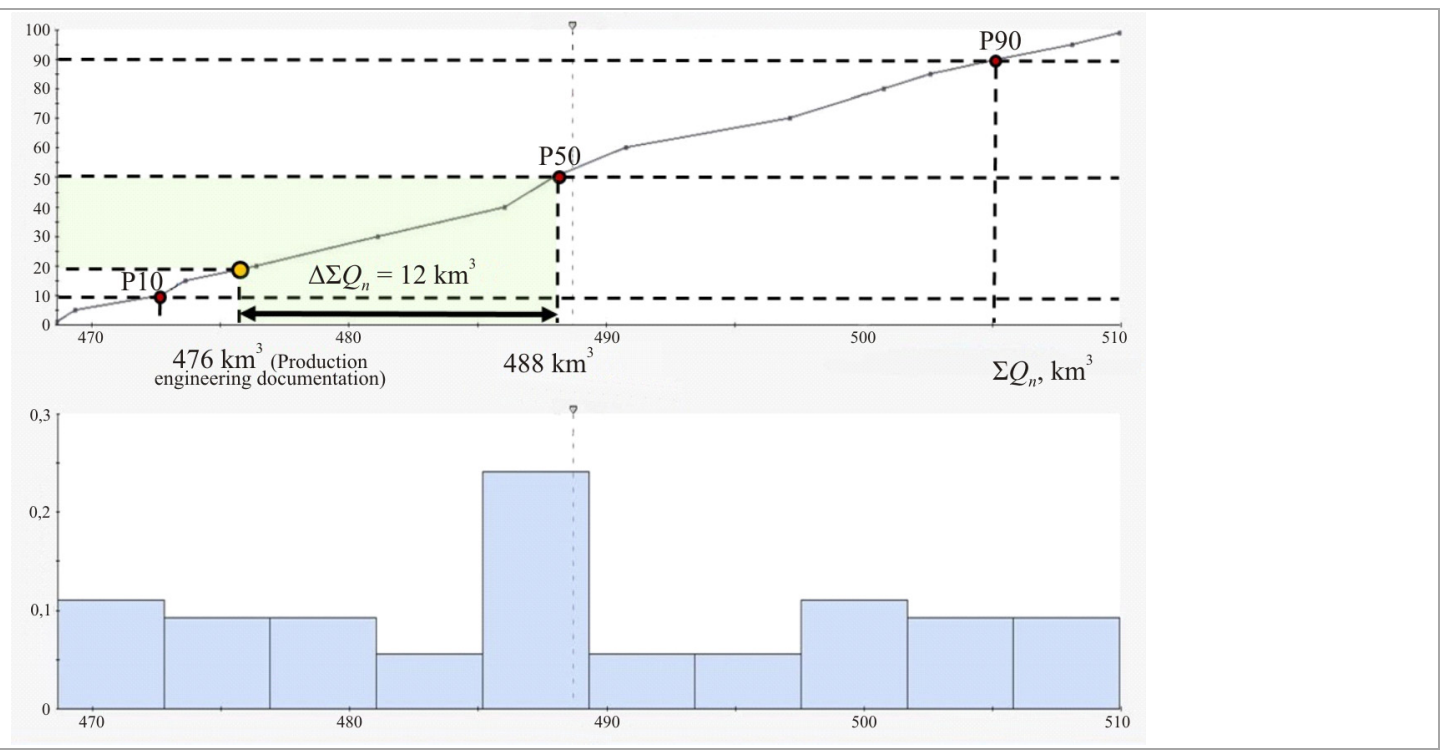

Fig. 5. Diagram of GHM calculations of density distribution with the plotted percentile

The percentile shows that it is possible to separate the most probable or pessimistic level of the cumulative oil production (P10), the optimal level (P50) is almost always close to the mathematical expectation, which is the level most frequently forecasted by GHM, and the most optimistic oil production level (P90). Also, the percentile marks the oil production level approved by the present design document on the Soldatovskoye oil field development within the Tournaisian reservoir of the Kukleyanovskoye uplift. As the oil production level approved by the production engineering documentation is lower than P50 by 12 thou. $\mathrm{m}^{3}$, then it is possible to state a moderate potential for the site under development.

In addition, the percentile analysis makes it possible to conclude that the cumulative oil production level, approved in the current field development design documentation, will be confirmed with the probability of $81 \%$, according to the calculations based on the geological and hydrodynamic reservoir model.

As the Kukleyanovskoye uplift is taken as a separate site, it reached an early development stage and has a small amount of geological and mobile oil reserves, the increase of 12 thou. $\mathrm{m}^{3}$ will be sufficient to strengthen the commercial effectiveness of the investment project.

Otherwise, if the GHM calculations produce a value of oil production level of percentile P50, which is less than in the approved development project, one risks a project profitability decline. Therefore, it is necessary to consider uncertainties that may impact a project profitability in cases of either promising and important fields being developed at an early stage, or fields with a small volume of geological and mobile oil reserves [35-37].

All the data are further acummulated in a generalized algorithm to analyze the impact of uncertainties and assess risks for the technological and commercial effectiveness of an investment project, which, in fact, can be applied to assets being developed at an early stage (Fig. 6) [38-45].

This algorithm may be modified and addded depending on the level of studies, development stage, economical and political factors.

\section{Conclusions}

The completed study has resulted in selecting uncertainty parameters and their range of variations. Also, we have performed the multivariant adaptation, which allows specifying the range of variations of earlier selected uncertainty parameters.

The sensitivity analysis, or the factor analysis, made it possible to conclude that the absolute permeability multiplier within the area of the producing wells (indirectly accounting for an influence of fractures on the fluid filtration in the reservoir) and functions of the relative phase 


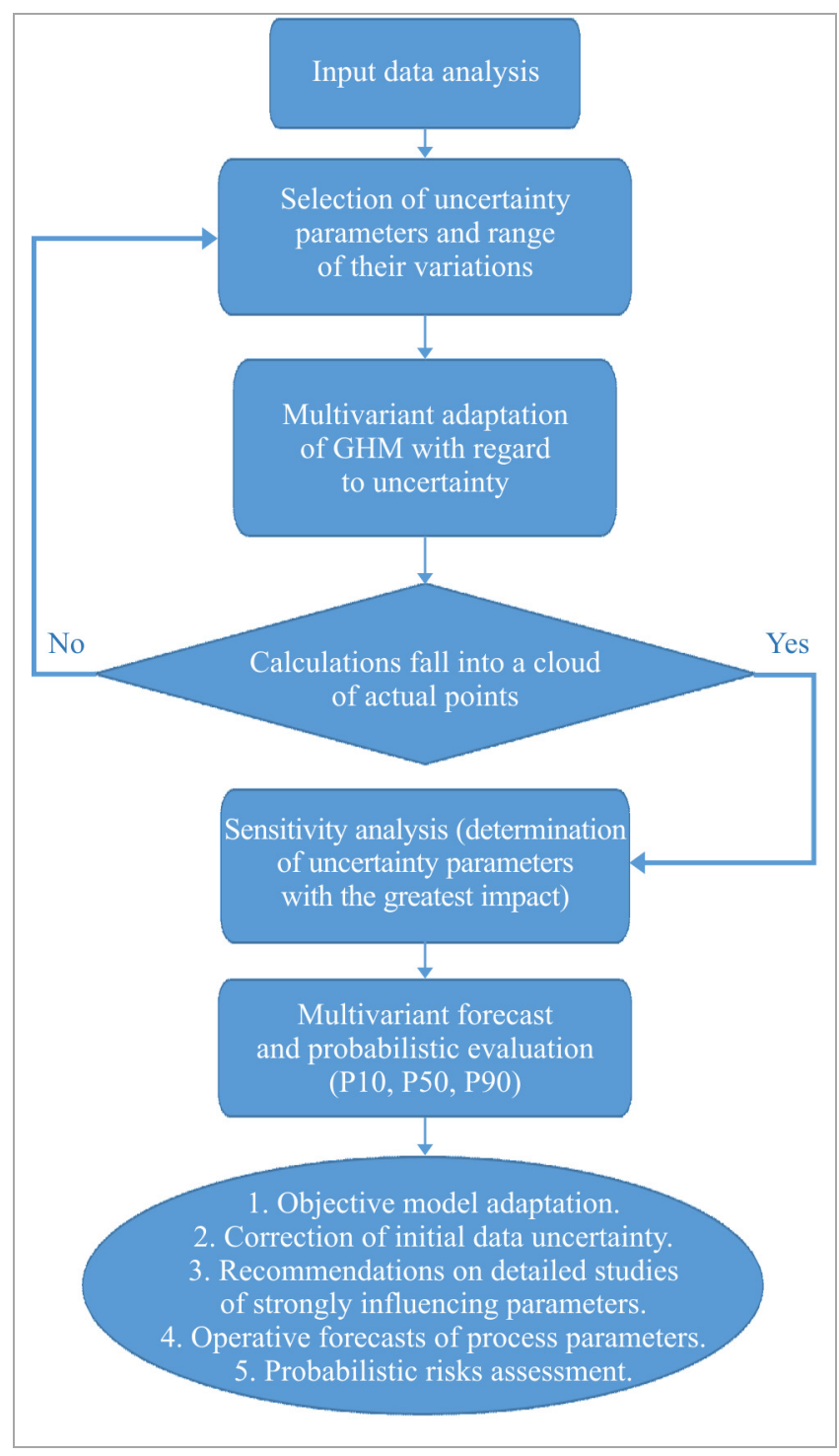

Fig. 6. Algorithm of impacts of uncertainties and risk assessment analysis

permeability have a great impact on the cumulative oil production. A more detailed study of these parameters is recommended.

Based on the obtained data, the multivariant forecast allowed completing a probabilistic evaluation and identifying pessimistic (P10), optimal (P50) and optimistic (P90) oil production levels in 2056. It is determined that the optimal (P50) level of the cumulative oil production is 12 thou. $\mathrm{m}^{3}$ higher than the level approved by the present production engineering documentation. Thus, we can conclude that it offers a slight potential.

The completed study offers the algorithm showing the impacts of uncertainties and risk assessment analysis. The latter allows optimizing the approach of the hydrodynamic model adaptation, making the adaptation process more objective and reliable, reducing uncertainty of input data, developing recommendations on further studies of assets, forecasting, evaluating the main production engineering parameters and performing the probabilistic risk assessment.

\section{References}

1. Gavura V.E. Geologiia i razrabotka neftianykh i gazoneftianykh mestorozhdenii [Geology and development of oil and gas-oil fields]. Moscow: VNIIOENG, 1995, 496 p.

2. Aziz Kh., Settari E. Matematicheskoe modelirovanie plastovykh sistem [Mathematical modeling of reservoir systems]. Moscow: Nedra, 1982, 407 p.

3. Krichlou G.B. Sovremennaia razrabotka neftianykh mestorozhdenii - problemy modelirovaniia [Modern oil field development modeling problems]. Moscow: Nedra, 1979, $303 \mathrm{p}$.

4. Nasybullin A.V., Antonov O.G. Postoianno deistvuiushchaia geologo-tekhnologicheskaia model' 3 bloka Berezovskoi ploshchadi [Permanent geological and technological model of block 3 of Berezovskaya area]. Sbornik nauchnykh trudov TatNIPIneft'. OAO "Tatneft'". Moscow: VNIIOENG, 2012, no. 80, pp. 91-95.

5. Kozyrev N.D, Ladeishchikova T.S, Zhulanov E.V. Modelirovanie geologotekhnicheskikh meropriiatii na Sibirskom mestorozhdenii (zalezh' Bsh-Srp) s ispol'zovaniem gidrodinamicheskogo simuliatora [Simulation of geological and technical measures at the Siberian field (Bsh-Srp deposit) using a hydrodynamic simulator]. Master's Journal, 2015, no. 1, pp. 238-244.

6. Rakhmanov A.R., Ibatullin R.R., Bakirov I.M., Nasybullin A.V., Antonov O.G. Sozdanie i ispol'zovanie postoianno deistvuiushchei geologotekhnologicheskoi modeli tret'ego bloka Berezovskoi ploshchadi [Development and application of permanently updated geological and reservoir model for the third block of the Berezovskaya area]. Neftianoe khoziaistvo, 2012, no. 2, pp. 54-56. 
7. Sazonov E.O. Hydrodynamic simulation of reservoir fluids filtration at diverter technology conditions. Oil and Gas Business: electronic scientific journal, 2013, iss. 3, pp. 109-119.

8. Gutman I.S. Balaban I.Iu. Metodologicheskie priemy otsenki riskov i neopredelennostei po zarubezhnym klassifikatsiiam [Methods of risks and uncertainties evaluation according to SPE-PRMS classification of reserves and resources]. Neftianoe khoziaistvo, 2014, no. 11, pp. 88-93.

9. Box G., Behnken D. Some new three level designs for the study of quantitative variables. Technometrics, 1960, vol. 2, pp. 455-475. DOI: $10.2307 / 1266454$

10. Todd M., Longstaff W. The Development, Testing and Application of a Numerical Simulator for Predicting Miscible Flood Performance. Journal of Petroleum Technology, 1972, vol. 24, no. 7, pp. 874-882. DOI: $10.2118 / 3484-\mathrm{PA}$

11. Gutman I.S. Metody podscheta zapasov nefti i gaza [Methods for calculating oil and gas reserves]. Moscow: Nedra, 1985, $244 \mathrm{p}$.

12. Gutman I.S. Balaban I.Iu. Geostatistika $\mathrm{v}$ promyslovo-geologicheskikh issledovaniiakh [Geostatistics in field geological research]. Moscow: Rossiiskii gosudarstvennyi universitet nefti i gaza, 2011, 154 p.

13. Palat Sankar, Torbatynia Mina, Kanadikirik Kerem, Varma Sunil. Hydrodynamic Modelling of Hydraulic Fracturing Fluid Injection in North Perth Basin Shale Gas Targets. SPE Asia Pacific Unconventional Resources Conference and Exhibition, 9-11 November. Brisbane, Australia. Conference Paper SPE-176879, 2015. DOI: $10.2118 / 176879-\mathrm{MS}$

14. Kovaleva L.A., Nasyrov N.M., Saiakhov F.L., Khismatullina F.S. Nestatsionarnaia fil'tratsiia mnogokomponentnoi uglevodorodnoi sistemy pri nalichii ob"emnogo istochnika tepla [Nonstationary filtration of a multicomponent hydrocarbon system in the presence of a volumetric heat source]. Izvestiia vuzov. Neft' i gaz, 1997, no. 3, pp. 37-42.
15. Golf-Rakht

T.D.

Osnovy neftepromyslovoi geologii i razrabotki treshchinovatykh kollektorov [Fundamentals of Oilfield Geology and Fractured Reservoir Development]. Moscow: Nedra, 1986, 608 p.

16. Cherepanov S.S., Martiushev D.A., Ponomareva I.N. Otsenka fil'tratsionnoemkostnykh svoistv treshchinovatykh karbonatnykh kollektorov mestorozhdenii Predural'skogo kraevogo progiba [Evaluation of filtration-capacitive properties of fractured carbonate reservoir of Predural'skogo edge deflection]. Neftianoe khoziaistvo, 2013, no. 3 , pp. $62-65$.

17. Myeong H. Noh, Larry W. Lake. Geochemical Modeling of Fracture Filling. SPE/DOE Improved Oil Recovery Symposium, 13-17 April. Tulsa, Oklahoma. Conference Paper SPE-75245, 2002. DOI: $10.2118 / 75245-M S$

18. Bortolan Neto L., Kotousov A. Residual opening of hydraulic fractures filled with compressible proppant. International Journal of Rock Mechanics and Mining Sciences, 2013, no. 61, pp. 223-230. DOI: $10.1016 /$ j.ijrmms.2013.02.012

19. Nils L. Jacobsen, Finn Engstrom, Uldall A., Niels W. Petersen. Delineation of Hydrodynamic/Geodynamic Trapped Oil in Low Permeability Chalk. SPE Annual Technical Conference and Exhibition, 3-6 October. Houston, Texas. Society of Petroleum Engineers SPE-56514, 1999. DOI: $10.2118 / 56514-M S$

20. Bourdet D. et al. A new set of type curves simplifies well test analysis. World oil, 1983, May, pp. 95-106.

21. William Thomas Peake, Rion Harl Camerlo, Terrell Tankersley. Tengiz Reservoir Uncertainty Characterization and Modeling. SPE Caspian Carbonates Technology Conference, 8-10 November. Atyrau, Kazakhstan. Conference Paper SPE-139561, 2010. DOI: $10.2118 / 139561-M S$

22. Denney D. Digital core laboratory: reservoir-core properties derived from 3D images. Journal of Petroleum Technology, 2004, vol. 56, iss. 05, pp. 66-88. DOI: $10.2118 / 0504-0066-J P T$ 
23. Ansari A.M., Sylvester N.D., Sarica C., Shoham O., Brill J.P. Comprehensive Mechanistic Model for Upward Two-Phase Flow in Wellbores. SPE Production \& Facilities, 1994, vol. 9, no. 2, pp. 143-151. DOI: $10.2118 / 20630-P A$

24. Jadhunandan P.P., Morrow N.R. Effect of wettability on waterflood recovery for crude-oil/brine/rock systems. SPE Reservoir Engineering, 1995, vol. 10 (1), pp. 40-46. DOI: 10.2118/22597-PA

25. Podio A.L., McCoy J.N., Becker D. Integrated well performance and analysis. $S P E$ Computer Applications, 1992, June, pp. 43-48. DOI: 10.2118/24060-PA

26. Nasybullin A.V., Antonov O.G., Shutov A.A., Rakhmanov A.R., Gumarov N.F., Ganiev B.G. Optimizatsiia sistemy zavodneniia na osnove trekhmernogo geologo-gidrodinamicheskogo modelirovaniia $i$ iskusstvennogo intellekta [3D reservoir modeling and AI-based optimization of waterflooding system]. Neftianoe khoziaistvo, 2012, no. 7, pp. 14-16.

27. Nasybullin A.V., Shutov A.A., Antonov O.G., Razzhivin D.A., Rakhmanov A.R., Ganiev B.G. Povyshenie effektivnosti neftedobychi pri optimizatsii sistemy zavodneniia na osnove neirosetevogo i gidrodinamicheskogo modelirovaniia [Increasing the efficiency of oil production while optimizing the waterflooding system based on neural network and hydrodynamic modeling]. Oborudovanie $i$ tekhnologii dlia neftegazovogo kompleksa, 2014, no. 5, pp. 47-51.

28. Sosnin N.E. Razrabotka statisticheskikh modelei dlia prognoza neftegazonosnosti (na primere terrigennykh devonskikh otlozhenii Severo-Tatarskogo svoda) [Development of statistical models for predicting oil-and-gas content (on the example of terrigenous devonian sediments of North Tatar arch)]. Vestnik Permskogo natsional'nogo issledovatel'skogo politekhnicheskogo universiteta. Geologiia. Neftegazovoe $i$ gornoe delo, 2012, no. 5, pp. 16-25.

29. Dement'ev L.F. Statisticheskie metody obrabotki i analiza promyslovo-geologicheskikh dannykh [Statistical methods of processing and analysis of field-geological data]. Moscow: Nedra, 1966, 206 p.

30. Watson G.S. Statistic on spheres. New York: John Wiley and Sons, Inc., 1983, 238 p.

31. Putilov I.S., Galkin V.I. Primenenie veroiatnostnogo statisticheskogo analiza dlia izucheniia fatsial'noi zonal'nosti turnefamenskogo karbonatnogo kompleksa Sibirskogo mestorozhdeniia [The results of statistical analysis for study fades characterization of T-Fm stage of Sibirskoe oilfield]. Neftianoe khoziaistvo, 2007, no. 9, pp. 112-114.

32. Sazonov E.O. Zeigman Iu.V. Analiz chuvstvitel'nosti modeli $\mathrm{k}$ neopredelennostiam $\mathrm{v}$ usloviiakh primeneniia potokotkloniaiushchikh tekhnologii. Ekspress-metod otsenki effektivnosti tekhnologii [Sensitivity model analysis under diverter technology conditions and uncertainties. Express method of efficiency estimation]. Neftianoe khoziaistvo, 2014, no. 10, pp. 102-105.

33. Mirzadzhanzade A.Kh., Stepanova G.S. Matematicheskaia teoriia eksperimenta $\mathrm{V}$ dobyche nefti i gaza [Mathematical theory of experiment in oil and gas production]. Moscow: Nedra, 1977, 228 p.

34. Gmurman V.E. Teoriia veroiatnostei i matematicheskaia statistika [Theory of Probability and Mathematical Statistics]. 10nd ed. Moscow: Vysshaia shkola, 2004, $479 \mathrm{p}$.

35. Safin D.K. Metodika veroiatnostnostatisticheskoi otsenki koeffitsienta izvlecheniia nefti iz zalezhei na razlichnykh stadiiakh ikh izuchennosti [Methodology for the probabilistic-statistical assessment of the oil recovery factor from deposits at various stages of their study]. Neft' $i$ gaz, 2001, no. 4, pp. 63-66.

36. Yarus J.M. Stochastic modeling and geostatistics. AAPG. Tulsa, Oklahoma, 1994, $231 \mathrm{p}$.

37. Latyshova M.G. et al. Prakticheskoe rukovodstvo po interpretatsii dannykh GIS [A practical guide to interpreting well log data]. Moscow: Nedra, 2007, 327 p. 
38. Lebedev T.S. Model studies of physical properties of mineral matter in high pressure temperature experiments. Phys. Earth and Planet. Inter, 1980, vol. 25, pp. 292-303. DOI: 10.1016/0031-9201(80)90126-0

39. Parzen E. On estimation of a probability density function and mode. Annals of Mathematical Statistics, 1962, vol. 33, pp. 1065-1076. DOI: 10.1214/aoms/1177704472.

40. Gladkov E.A. Geologicheskoe i gidrodinamicheskoe modelirovanie mestorozhdenii nefti i gaza: uchebnoe posobie [Tutorial Geological and hydrodynamic modeling of oil and gas fields]. Tomsk: Tomskii politekhnicheskii universitet, 2012, pp. 25-35. 87 p.

41. Gimazov A.A., Fokeeva E.E., Khairullin R.U., Minikhanov D.M. Kompleksnyi podkhod $\mathrm{k}$ adaptatsii i prognozu parametrov vtorichnoi pustotnosti dlia neftianogo mestorozhdeniia imeni R. Trebsa [Integrated approach to adapting and forecasting the parameters of secondary porosity for the R. Trebs oilfield]. Neftianoe khoziaistvo, 2018, no. 10 , pp. $20-23$. DOI: $10.24887 / 0028-2448-$ 2018-10-20-23

42. Zakirov R.Kh. Rol' geologogidrodinamicheskogo modelirovaniia pri proektirovanii razrabotki neftianykh mestorozhdenii [Role of geologicalhydrodynamic modelling at designing of oil field development]. Georesursy, 2009, no. 4, pp. 34-36.

43. Bozheniuk N.N., Strekalov A.V. Nekotorye priemy adaptatsii gidrodinamicheskoi modeli $\mathrm{k}$ istorii razrabotki [Some methods of simulation model historymatching]. Neftegazovoe delo, 2016, no. 2, pp. 42-49.

44. Belov K.V., Lisenkov A.B., Ponomarev A.D., Gorbatenko N.S. Issledovanie protsessov fil'tratsii vody $\mathrm{v}$ poristoi srede metodami fizicheskogo i chislennogo modelirovaniia [Study of fluid filtration in a porous medium using physical and numerical modeling]. Izvestiia Tomskogo politekhnicheskogo universiteta. Inzhiniring georesursov, 2017, vol. 328, no. 8, pp. 64-74.
45. Dikalov D.V. Kompleksnyi podkhod $\mathrm{k}$ sozdaniiu postoiannodeistvuiushchei geologo-tekhnologicheskoi modeli (na primere Zapadno-Tugrovskogo mestorozhdeniia) [Comprehensive approach to the construction of a permanently working geologicaltechnological model on the example of the Western-Tugrovsky deposit]. Geologiia, geofizika $i$ razrabotka neftianykh $i$ gazovykh mestorozhdenii, 2018, no. 9, pp. 34-40. DOI: 10.30713/2413-5011-2018-9-34-40

\section{Библиографический список}

1. Гавура В.Е. Геология и разработка нефтяных и газонефтяных месторождений. М.: ВНИИОЭНГ, 1995. - 496 с.

2. Азиз Х., Сеттари Э. Математическое моделирование пластовых систем. - М.: Недра, 1982. - 407 c.

3. Кричлоу Г.Б. Современная разработка нефтяных месторождений - проблемы моделирования. - М.: Недра, 1979. 303 c.

4. Насыбуллин А.В., Антонов О.Г. Постоянно действующая геолого-технологическая модель 3 блока Березовской площади // Сб. научных трудов ТатНИПИнефть / ОАО «Татнефть». - М.: Изд-во ВНИИОЭНГ, 2012. - № 80. - С. 91-95.

5. Козырев Н.Д., Ладейщикова Т.С., Жуланов Е.В. Моделирование геологотехнических мероприятий на Сибирском месторождении (залежь Бш-Срп) с использованием гидродинамического симулятора // Master's Journal. - 2015. № 1. - Р. 238-244.

6. Создание и использование постоянно действующей геолого-технологической модели третьего блока Березовской площади / А.Р. Рахманов, Р.Р. Ибатуллин, И.М. Бакиров, А.В. Насыбуллин, О.Г. Антонов // Нефтяное хозяйство. - 2012. - № 2. C. 54-56.

7. Sazonov E.O. Hydrodynamic simulation of reservoir fluids filtration at diverter technology conditions // Oil and Gas Business: electronic scientific journal. - 2013. - Iss. 3. P. 109-119. 
8. Гутман И.С. Балабан И.Ю. Методологические приемы оценки рисков и неопределенностей по зарубежным классификациям // Нефтяное хозяйство. 2014. - № 11. - C. 88-93.

9. Box G., Behnken D. Some new three level designs for the study of quantitative variables // Technometrics. 1960. - Vol. 2. - P. 455-475. DOI: $10.2307 / 1266454$

10. Todd M., Longstaff W. The Development, Testing and Application of a Numerical Simulator for Predicting Miscible Flood Performance // Journal of Petroleum Technology. - 1972. Vol. 24, № 7 . - P. 874-882. DOI: $10.2118 / 3484-P A$.

11. Гутман И.С. Методы подсчета запасов нефти и газа. - М.: Недра, 1985. 244 c.

12. Гутман И.С. Балабан И.Ю. Геостатистика в промыслово-геологических исследованиях. - М.: РГУ НГ, 2011. $154 \mathrm{c}$.

13. Hydrodynamic Modelling of Hydraulic Fracturing Fluid Injection in North Perth Basin Shale Gas Targets / Sankar Palat, Mina Torbatynia, Kerem Kanadikirik, Sunil Varma // SPE Asia Pacific Unconventional Resources Conference and Exhibition, 9-11 November. - Brisbane, Australia. Conference Paper SPE-176879, 2015. DOI: $10.2118 / 176879-\mathrm{MS}$.

14. Нестационарная фильтрация многокомпонентной углеводородной системы при наличии объемного источника тепла / Л.А. Ковалева, Н.М. Насыров, Ф.Л. Саяхов, Ф.С. Хисматуллина // Известия вузов. Нефть и газ. - 1997. - № 3. C. $37-42$.

15. Голф-Рахт Т.Д. Основы нефтепромысловой геологии и разработки трещиноватых коллекторов. - М.: Недра, 1986. -608 c.

16. Черепанов С.С., Мартюшев Д.А., Пономарева И.Н. Оценка фильтрационноемкостных свойств трещиноватых карбонатных коллекторов месторождений Предуральского краевого прогиба //
Нефтяное хозяйство. - 2013. - № 3. C. 62-65.

17. Myeong H. Noh, Larry W. Lake. Geochemical Modeling of Fracture Filling // SPE/DOE Improved Oil Recovery Symposium, 13-17 April. - Tulsa, Oklahoma. Conference Paper SPE-75245, 2002. DOI: $10.2118 / 75245-M S$

18. Bortolan Neto L., Kotousov A. Residual opening of hydraulic fractures filled with compressible proppant // International Journal of Rock Mechanics and Mining Sciences. - 2013. - №61. - P. 223-230. DOI: 10.1016/j.ijrmms.2013.02.012

19. Delineation of Hydrodynamic/ Geodynamic Trapped Oil in Low Permeability Chalk / Nils L. Jacobsen, Finn Engstrom, A. Uldall, Niels W. Petersen // SPE Annual Technical Conference and Exhibition, 3-6 October. - Houston, Texas. Society of Petroleum Engineers SPE-56514, 1999. DOI: $10.2118 / 56514-\mathrm{MS}$

20. A new set of type curves simplifies well test analysis / D. Bourdet [et al.] // World oil. - 1983. - May. P. 95-106.

21. William Thomas Peake, Rion Harl Camerlo, Terrell Tankersley. Tengiz Reservoir Uncertainty Characterization and Modeling // SPE Caspian Carbonates Technology Conference, 8-10 November. - Atyrau, Kazakhstan. Conference Paper SPE-139561, 2010. DOI:10.2118/139561-MS

22. Denney D. Digital core laboratory: reservoir-core properties derived from 3D images // Journal of Petroleum Technology. 2004. - Vol. 56, iss. 05. - P. 66-88. DOI: 10.2118/0504-0066-JPT

23. Comprehensive Mechanistic Model for Upward Two-Phase Flow in Wellbores / A.M. Ansari, N.D. Sylvester, C. Sarica, O. Shoham, J.P. Brill // SPE Production \& Facilities. - 1994. - Vol. 9, № 2. - P. 143-151. DOI: $10.2118 / 20630-P A$

24. Jadhunandan P.P., Morrow N.R. Effect of wettability on waterflood recovery for crudeoil/brine/rock systems // SPE Reservoir Engineering. - 1995. - Vol. 10 (1). - P. 40-46. DOI: $10.2118 / 22597-P A$ 
25. Podio A.L., McCoy J.N., Becker D. Integrated well performance and analysis // SPE Computer Applications. - 1992. - June. P. 43-48. DOI: $10.2118 / 24060-P A$

26. Оптимизация системы заводнения на основе трехмерного геолого-гидродинамического моделирования и искусственного интеллекта / А.В. Насыбуллин, О.Г. Антонов, А.А. Шутов, А.Р. Рахманов, Н.Ф. Гумаров, Б.Г. Ганиев // Нефтяное хозяйство. - 2012 . - № 7 . C. $14-16$.

27. Повышение

эффективности нефтедобычи при оптимизации системы заводнения на основе нейросетевого и гидродинамического моделирования / А.В. Насыбуллин, А.А. Шутов, О.Г. Антонов, Д.А. Разживин, А.Р. Рахманов, Б.Г. Ганиев // Оборудование и технологии для нефтегазового комплекса. - 2014. - № 5. C. $47-51$.

28. Соснин

H.E.

статистических моделей для прогноза нефтегазоносности (на примере терригенных девонских отложений Северо-Татарского свода) // Вестник Пермского национального исследовательского

политехнического университета. Геология. Нефтегазовое и горное дело. - 2012. - № 5. - С. 16-25.

29. Дементьев Л.Ф. Статистические методы обработки и анализа промысловогеологических данных. - М.: Недра, 1966. 206 c.

30. Watson G.S. Statistic on spheres. New York: John Wiley and Sons, Inc., 1983. $238 \mathrm{p}$.

31. Путилов И.С., Галкин В.И. Применение вероятностного статистического анализа для изучения фациальной зональности турнефаменского карбонатного комплекса Сибирского месторождения // Нефтяное хозяйство. - 2007. - № 9. C. $112-114$.

32. Сазонов Е.О. Зейгман Ю.В. Анализ чувствительности модели к неопределенностям в условиях применения потокотклоняющих технологий. Экспресс-метод оценки эффективности технологии // Нефтяное хозяйство. - 2014. - № 10. - С. 102-105.
33. Мирзаджанзаде А.Х., Степанова Г.С. Математическая теория эксперимента в добыче нефти и газа. - М.: Недра, 1977. $228 \mathrm{c}$.

34. Гмурман B.E. Теория вероятностей и математическая статистика: учеб. пособие для вузов. - 10-е изд., стереотип. - М.: Высшая школа, 2004. - 479 с.

35. Сафин Д.К. Методика вероятностностатистической оценки коэффициента извлечения нефти из залежей на различных стадиях их изученности // Нефть и газ. 2001. - № 4. - С. 63-66.

36. Yarus J.M. Stochastic modeling and geostatistics / AAPG. - Tulsa, Oklahoma, 1994. - $231 \mathrm{p}$.

37. Практическое руководство по интерпретации данных ГИС / М.Г. Латышова [и др.]. - М.: Недра, 2007. 327 c.

38. Lebedev T.S. Model studies of physical properties of mineral matter in high pressure - temperature experiments // Phys. Earth and Planet. Inter. - 1980. - Vol. 25. - P. 292-303. DOI:10.1016/0031-9201(80)90126-0.

39. Parzen E. On estimation of a probability density function and mode // Annals of Mathematical Statistics. 1962. - Vol. 33. - P. 1065-1076. DOI: $10.1214 /$ aoms/1177704472.

\section{0. Гладков Е.А. Геологическое} и гидродинамическое моделирование месторождений нефти и газа. - Томск: Изд-во Томск. политехн. ун-та, 2012. C. $25-35 .-87$ c.

41. Комплексный подход к адаптации и прогнозу параметров вторичной пустотности для нефтяного месторождения имени Р. Требса / А.А. Гимазов, Е.Е. Фокеева, Р.У. Хайруллин, Д.М. Миниханов // Нефтяное хозяйство. 2018. - № 10 . - С. 20-23. DOI: 10.24887/0028-2448-2018-10-20-23

42. Закиров Р.Х. Роль геологогидродинамического моделирования при проектировании разработки нефтяных месторождений // Георесурсы. - 2009. № 4. - С. 34-36. 
43. Боженюк Н.Н., Стрекалов А.В. Некоторые приемы адаптации гидродинамической модели к истории разработки // Нефтегазовое дело. - 2016. - № 2. C. 42-49.

44. Исследование процессов фильтрации воды в пористой среде методами физического и численного моделирования / К.В. Белов, А.Б. Лисенков, А.Д. Пономарев, Н.С. Горбатенко // Известия Томского политехнического университета. Инжиниринг георесурсов. 2017. - Т. 328, № 8. - С. 64-74.

45. Дикалов Д.В. Комплексный подход к созданию постоянно действующей геолого-технологической модели (на примере Западно-Тугровского месторождения) // Геология, геофизика и разработка нефтяных и газовых месторождений. - 2018. - № 9. - С. 34-40. DOI: $10.30713 / 2413-5011-2018-9-34-40$

Please cite this article in English as:

Kozyrev N.D., Vishnyakov A.Yu., Putilov I.S. Assessment of the Uncertainty Parameters Influence on the Development Indicators Forecasting. Perm Journal of Petroleum and Mining Engineering, 2020, vol.20, no.4, pp.356-368. DOI: 10.15593/2712-8008/2020.4.5

Просьба ссылаться на эту статью в русскоязычных источниках следующим образом:

Козырев Н.Д., Вишняков А.Ю., Путилов И.С. Оценка влияния параметров неопределенности на прогнозирование показателей разработки // Недропользование. - 2020. - Т.20, №4. - С.356-368. DOI: $10.15593 / 2712-8008 / 2020.4 .5$ 